\title{
Does Indonesian Ulama Council (IUC) Has Manipulated the Islamic Law by Implementing Hybrid Contract in Islamic Insurance (Ta'mîn)?
}

\author{
Burhanuddin Susamto \\ Department of Business Law, State Islamic University Maulana Malik Ibrahim, Indonesia
}

\begin{abstract}
It is a fact that insurance (ta'min) has become one of products of financial institution promising benefit guarantee for human. Nevertheless presence of insurance has provoked debate among contemporary Muslim scholars related to its validity. Some of them believe that insurance is absolutely forbidden due to the element of gambling and others allow it because there is benefit (al-maslahah). Indonesian Ulama Council (IUC) is a clerical institution that allows insurance products through an approach of hybrid contract. Through this article, the author will reveal whether IUC has legalized gambling through implementation hybrid contract (al-'uqûd al-murakkabah) in the formation of insurance products.
\end{abstract}

Keywords: IUC, Gambilng, Hybrid Contract, Insurance

\section{Introduction}

Provision of guarantees through insurance model (ta'min) widely applied in Indonesia, both related to business interests and social insurance programs organized by the government. Insurance program managed by business institutions is voluntary, while social insurance programs is a compulsory insurance program based on a law which has the objective of providing protection for the welfare of the public. According law, compulsory insurance program is a program that required legislation for all or certain groups in society in order to get protection from certain risks with a cross-subsidy mechanism in determining the benefits and premiums/ contribution.

Insurance other than as the product of financial business to get profit, it is a system of underlying transaction for realizing social security program which is organized by The Implementing Agency of Social Security (IASS) as legal entity formed base on law. Social security means one of the social protections that given to guarantee the entire people in order to be capable in fulfilling their appropriate basic need, as mandated in Article 28H section (1), section (2), and section (3) and Article 34 section (1) and section (2) of the Constitution of the State the Republic of Indonesia Year 1945.

The main characteristic of insurance is premium payments as compensation for services of underwriting risks. In insurance agreement there is a transfer of risk from the participants to the insurance company as service providers. So that the possibility of whether there is a risk that happening has led to speculation for both parties the insurer and the insured. In addition to the management of funds in financial institutions based on usury (riba) also become a central issue of insurance in force in Indonesia, although the interpretation of usury itself varies. The fact that practice speculation, usury, etc in insurance is then stirred debate among contemporary Islamic scholars whether the law of insurance is valid or invalid.

The debate of insurance law among contemporary of Islamic scholars not only at the level of validity of insurance as a product, but also related to the contracts recomendation which is used in it product, primarily from among those who received the insurance. Islamic scholars who forbid validity of insurance like Sayid Sabiq (author Fiqh as-Sunnah), Abdullah Al-Qalqili (Mufti Jordan), Muhammad Yusuf Qordawi (author of alHalal wa fi al-Haram al-Islam), and Muhammad Bakhit Al-Muth'i (Mufti of Egypt). While they, the great scholar who accept insurance such as Abdul Wahab Khalaf (author of Ushul al-Fiqh), Mustafa Ahmad Zarqa (Professor of Islamic Law at the Faculty of Islamic University of Syria), Muhammad Yusuf Musa (Professor of Islamic Law at Cairo University, Egypt), Mohammed Nejatullah Siddiq, and Abdurahman Isa (the author of alMuamallah Ahkamuha wa al-Haditha).

Term insurance according perspective of Islamic law called al-ta'min (الأمن meaning inner peace or the loss of fear. Besides that, ta'mîn derives from al-amânah which is the antonym of treacherous. Ta'min agreement is a mutual agreement where the insured binds to the insurer who gives insurance guarantee for welfare by financial reimbursement as agreed. Ta'mîn represent an agreement of two parties which requires the insurer to provide the insured benefits such as some money, income, or compensation in the event of calamity or risks contained in the agreement.

According Insurance Law has stated that Islamic Insurance is a collection agreement which consists of an agreement between the Islamic insurance company and the policyholder and the agreement between the 
olicyholder in order to manage the contribution based on Islamic principles in order to help and protect each other by means of: (a) Reimburse the participant or policyholder for loss, damage, costs incurred, lost profits, or legal liability to third parties that may be suffered by participants or policyholders because of the occurrence of an uncertain event; or (b) Provide payment based on the participant's death or payment based on the life of participants with a predetermined amount of benefits and/ or based on the results of fund management.

Of definition above it can be understood that Islam insurance is not only an agreement of two parties but aslo collection agreement, because there many parties involved such as agreement between insurance company with participants collectively and agreement among participant individually for helping one another. In this context service of insurance company only as a fund manager, accumulation of premium and then distribution to participants who get disaster. That definition in the legislation is identical to the definitions in fatwa of Indonesian Ulama Council (IUC) who stated Islamci Insurance (ta'min, takaful, tadhamun) is an attempt to protect and mutual assistance each other among a number of people/ parties through investment in assets and/ or tabarru' by repayment to face particular risks through agremeent which in accordance with shari'a.

Islamic insurance has offered an alternative concept to legitimize existing practices and to avoid resistance from parties who refused. IUC may not be refused insurance products because it has a lot of benefits for society, especially for poor citizents who had got social security programs from governement which its distribution based on insurance system. Practice specualation and usury of insurance then it is improved through approach of Islamic contracts. Fact hat their offering could not replace previous established concept because it was widely practiced by the public, so for solution imposed insurance by the dual system. To develop certain product of Islamic insurance, IUC have used approach of hybrid contracts of which has raised new debat. Does by hybrid contracts IUC has manipulated Islamic law for legitimating praktice of insurance previously?

Hybrid contracts, although widely applied in different countries, it theoretically still scarce because it specifically was not discussed in the classical books. Contemporary scholars who wrote hybrid contracts inbetween: Al-Imrânî by his work, al-'Uqûd al-Mâliyah al-Murakkabah: Dirâsat Fiqhiyah Ta'shiliyah wa Tathbîqiyah; Nazîh Hammâd, al-'Uqûd al-Murakkabah fî̀ al-Fiqh al-Islâmî, Hasanuddin in his dicertation research, The Concept and Standard of Hybrid Contracts in Fatwa DSN-MUI. That works is quite inspiring about the permissibility of using hybrid contracts for developing of financial product although hadith tends to forbid it.

The aim of this papers is to elaborate forms of contracts used by the IUC in middle of contemporary debate of insurance law that has not been final, and to determine whether a hybrid contract approach as part of manipulation of Islamic law in Indonesia.

\subsection{Definition}

\section{The Theory of Hybrid Contracts}

The term hybrid contracts in Arabic called al-'uqûd al-murakkabah. The word al-'uqûd plural of 'aqd which literally means agreement/ engagement. In term 'aqd (contract) is engagement or agreement (ijab qabul) in accordance with sharia view which creates legal effect on its object. The word al-murakkab is a ism maf'ul of the word ركب which etymologically means al-jam'u ie collect / gather. Al-Imrani termed hybrid contract with al-'uqûd al-maliyah al-murakkabah, namely a collection of business contract being integrated by way of combining or mutually accepting where all rights and obligations strung as a single contract.

\subsection{Classification of Hybrid Contracts}

Hybrid contracts as approach the one hand is a necessity, but on the other hand feared conflict with the shari'a principles. According to the authors, the implementation of hybrid contracts either there is caused by dependence on each other by nature (al-'uqûd al-murakkabah al-thabî'îyah) or through modification process (al-'uqûd al-murakkabah al-ta'dîlah). Hybrid contracts formed by nature is permissible, for example, the relationship between the principal contract (al-'aqd al-ashli) like debt (al-qardh) with a contract that is followed (al-'aqd al-tabi'î) like pawning (al-rahn). It means that there is no pawning agreement without previously debt agreement. Both corelation shows that hybrid contracts by nature is necessity while the debate is at the level of the hybrid contract through modification.

Hybrid contracts formed by the nature tend to interconnected, so that followup (al-'aqd al-tabi'î) can only be applied if the principal contract (al-'aqd al-ashli) had been applied. That provision in line with Islamic legal maxim which states that followers should follow (al-tabi 'tabi') or the law of follower not separated from the principal (al-tabi 'lâ yufrad bi al-hukmi). Then, hybrid contracts product of modification is formed by some contracts each of which has independent characteristic. Modifying an independent contract would violate sharia principles if they not do according to the truth procedure.

In a modification of the contract, in general, there are three possibilities to do, namely: first, combine fellow of commercial contract (mu'âwadlah). Second, combine a commercial contract (mu'âwadhah) with 
charity contract (tabarru'). And third, combine fellow of charity contracts (tabarru). The combination of the same or different contract is permissible, as long as the requirements of each contract is fulfilled.

Al-'Imrani had divided hybrid contracts into five types, namely interdependence contracts (al-'uqûd almutaqâbilah), accumulated contracts (al-'uqûd al-mujtami'ah), opposites contracts (al-'uqûd al-mutanâqidhah wa al-mutadhâdah wa al-mutanâfiyah), different contracts (al-'uqûd al-mukhtalifah), and identical contracts (al'uqûd al-mutajânisah). His clacification is only emphasizes the nature of the contract that have possibility is incorporated in hybrid contracts.

\subsection{Legal Caution and Its Interpretation}

A contract has been said to be realized if the pillars of the contract fulfilled. But in terms of validity, an agreement still depends on whether requirements of shar'a have complianced or not. The legal consequences of inappropriate contract is divided into two, namely invalid (batal) and imperfect (fasid). Cancel occurs when at the start of the contract is not in accordance with the conditions stipulated in Islamic law. While invalid contract different from the imperfect contract which will only occur if it previously legitimate, but because there are certain reasons that damage the countenance ('uyub al-rida) so the contract be imperfect. According to jurists Hanafiyah, imperfect contract agreement is valid in principle, but not legitimate in nature. That is despite the imperfect contract has qualified the formation of the contract, but not yet eligible validity. However the majority of jurists (besides Hanafiyah) did not distinguish because they considered that both contracts equally invalid so it does not provide any legal consequences.

Hybrid contract by modification of the contract is part of legal finding (ijtihad) in order to some contracts contained in islamic law (fiqh) can be applied in modern transaction. Permissibility of contracts modification must be based on the validity of each contract that form it. That is, the modification of the contract is called valid if the pillars and terms completed, in addition to keep limitations set forth shari'a relating to prohibition of smelting contract. There are some traditions that give caution to hybrid contracts, such prophet statemen:

\begin{tabular}{|c|c|c|}
\hline No & Sayings (Hadits) of Prophet & Meaning \\
\hline 1 & نهى رسول الله صلى الله عليه وسلَم عن صفقتين في صفقة واحدة & The prophet prohibited two contracts in one transaction \\
\hline 2 & عن أبسي هريرة قـال: نهى رسـول الله صلى الله عليه وسلُم عن بيعتين & $\begin{array}{l}\text { The prophet prohibited the two trading contract in a } \\
\text { single trading contract }\end{array}$ \\
\hline 3 & ولا يحلّ سلف ما ليس وبيع، ول لا شرطان في بيع، و لا ربح ما لم يضمن، & $\begin{array}{l}\text { Not lawful combine debt contract with purchase } \\
\text { contract, the two terms of the purchase, the advantages }\end{array}$ \\
\hline
\end{tabular}

The substance of the those hadith have create differences of opinion in interpretation whether hybrid contract is prohibited or not.

Word صفقة in the language means slapped hands when contract (dharb al-yad 'inda al-'aqd), while in terms it means the contract itself. Customs of the Arabs when selling binding (lazim) then one party (eg the seller) slammed his hand on the hands of the other party (the buyer). Therefore pronunciations hadith shafqatain fi shadaqah wahidah means two contract agreements in one contract. Term contract here is general agreement that could apply to all contract absolutely without any particular limitations. The understanding of such hadits was based on the rules of ushul figh which states that the pronunciation is absolutely fixed in absoluteness as long as there is no proposition that restrict it (al-muthlaqu yajrî 'ala ithlâqihi ma lam yakum dalil al-taqyid).

If the first hadith related to prohibition of combining the two contract into one, then the second hadith specializes prohibition of combining combining the two purchase contract into a one. Islamci Scholar many different opinions in interpreting the two trading contract in a single trading contract (bai'ataîn fi baî'atin). The most selected opinions (rajih) is who interprets that someone is selling at a price of credit, then require the buyer to sell back with the cash price. According to another interpretation, the prohibition is prevail because it causes usury.

Based on that explanation, the hybrid contract which combine a trading contract with a debt contract is prohibited. But that prohibition only prevail specific, does not prevail to all hybrid contract which according to the original law is allowed. Nazih Hammad said that permissibility of hybrid contract prevail generally, while some hadith of the prophet which forbids hybrid contract is specific prevailing. Legal exceptions can not be applied in all practice of transaction containing hybrid contract.

Aliudin Za'tary in his book: al-Fiqh al-Maliyah al-Muqaran said that there is no prohibition in the shari'a on the merger of the two contract in one transaction, either commercial contract (mu'âwadhah) or charity contract (tabarru'). This argument based on the generality of the postulates ordering to meet the terms in agreement/ contract as described in (QS. Al-Maidah[5]: 1). 


\section{Hybrid Contract in Islamic Insurance}

Indonesian Ulama Council (IUC) tend to accept the existence of insurance by offering an alternative concept uses islamic contracts as underlying transactions. Through fatwa Number. 21/DSN-MUI/X/2001, IUC had stated that the agreement between participants and company consists of tijârah and/or tabarru'. Tijârah is all forms of contract for commercial purposes, while tabarru' is all forms of contract for social purposes. Commercial contract uses mudhârabah and social contract uses hibah both of which simultanously applied when the participant pays premium. Premium is the obligation of insurance participants to pay some amount of money to the insurance company based on the deal in the agreement. Every participant who pays the premium means he automatically has invested through mudhârabah agreement and also do the charity through hibah agreement. The participant who pay the premium has a claim right which must be guaranteed by the insurance company as stated in insurance policy.

Through tijârah contract (mudhârabah), the company acts as the manager (mudhârib) and the participant acts as the policyholder (shâhibul mâl). If the management results in profits, then it will be shared between the company and the participant based on the agreed ratio. On the other hand, if there is loss in managing the investment fund, there is no exact provision in IUC's fatwa. Tijârah can be changed into tabarru' if the owner volunteers his right to acts of kindness to others.

Through tabarru' contract (hibah), the participants give charity which will be used to help the other participants affected by calamity, and the company acts as manager of charity fund who represent all participants. Tabarru' contract is an agreement which must adhere in all insurance products. Tabarru' contract in insurance is all forms of agreement made among paricipants as the policy holders who individually has right to receive charity funds (mu'amman/mutabarra' lahu) and collectively as insurers (mu'ammin/mutabarri').

In managing charity funds, the contract is used by the participants and the insurance company is wakâlah bil ujrah namely delegation of authority from the participants to the insurance company to manage the participants' funds by compensation in the form of fee (ujrah). In this case, the company acts as the representative (wakil), while the participants act as the party to be represented (muwakkil). If the management of charity funds results financial profit, then it is put in tabarru' account belonging to the participants collectively. But, if there is loss then the company as the wakil is not obliged to refund because characteristic of wakâlah contract is a trustful agreement (yad amanah) and not bearing agreement (yad dhamanah), unless they as wakil proven negligence.

According fatwa Number 51/DSN-MUI/III/2006, the insurance company can put its own funds to be managed collectively with participants' fund. Although this model can optimize the role of the insurance company, but the effects may create a conflicts of interest that could harm participants. Underlying contract which is used to legitimate this concept is mudhârabah musytarakah namely combination of mudhârabah and musyarakah.

From the above explanation can be seen that IUC has implemented hybrid contracts in the development of Islamic insurance in Indonesia. The aim of it contract is to simplify the application of those contracts in financial products, and to avoid the ilegal practice like both unknown parties (gharar), gambling (maysir), and usury (riba) that are previously considered inherent in insurance products. Hybrid contract implemented by IUC used modification approach (al-'uqûd al-murakkabah al-ta'dîlah) by combining seceral relevant contracts each of which actually can be applied independently.

According to the author, modify the Islamic contracts ( $a$ - 'uqûd) in insurance product conducted by IUC is part of the manipulation of Islamic law, because terms of each contract can not be executed perfectly. If the terms of the contracts are not executed, consequently the validity of the agreement will be broken, for example, in Islam law there is no compulsion to give grants (hibah), but when hibah became part of the insurance contract, participants who do not pay it are penalized, etc. Beside that, the consequences of hybrid contract is that each party both insurance companies and participants have multiple roles at the same time thereby potentially cause ambiguity of transactions.

\begin{tabular}{|l|l|l|l|}
\hline No & Name of Contracts In Insurance Product & \multicolumn{3}{|l|}{ Both Parties } \\
\cline { 3 - 4 } & & Company Insurance & Participants \\
\hline 1 & Contract of equity sharing (mudhârabah) & $\begin{array}{l}\text { Investment fund managers } \\
(\text { mudhârib) }\end{array}$ & Investor s (shahib al-mâl) \\
\hline 2 & Contract of grant (hibah) & $\begin{array}{l}\text { Represent the grantee/ } \\
\text { participants (mauhub lahu) }\end{array}$ & Grantors (wahib) \\
\hline 3 & $\begin{array}{l}\text { Contract of agency with reward (wakalah } \\
\text { bi al- 'ujrah) }\end{array}$ & Agen of participants (wakil) & $\begin{array}{l}\text { Party who represent } \\
\text { (muwakkil) }\end{array}$ \\
\hline 5 & Contract of partnersip (musyarakah) & Partner (syarik) & Partners (syarik) \\
\hline
\end{tabular}




\section{Conclusion}

The prohibition of hadith regarding hybrid contract is only prevail specific, so it does not cover all modification of contract as efforts to develope financial products. Islamic insurance, one of financial products, can only be developed through a hybrid contract. Although IUC had issued some legal satement (fatwa) concerning hybrid contract in insurance product, but the fact there has been manipulation of Islamic law which led to the provision of islamic contracts (al-'uqûd) be broken.

\section{References}

[1]. Articel 1 poin 32 Law of Republic of Indonesia Number 40 Year 2014 concerning Insurance

[2]. Abdul Ghofur Anshori, Asuransi Syariah di Indonesia (Yogyakarta: UII Press, 2008) 10

[3]. Ibid. 11-12

[4]. Al-Râghib al-Ashfahânî, Al-Mufradât fì Gharîb al-Qur'ân (Riyâdh: Maktabah Musthafâ Bâz,2009) I/ 32

[5]. Hazîh Hammâd, Mu'zam al-Mushtalahât al-Mâliyah wa al-Iqtishâdiyah fí Lughat al-Fuqahâ (Jedah: Dâr al-Basyîr, 2008) 124

[6]. Mushtafâ Ahmad al-Zarqâ, Nizâm al-Ta'mîn (Haqîqah wa Ra'yu al-Syar'î Fîh) (Beirut: Muasasah al-Risalah, 1984) 19

[7]. Articel 1 Point 2, Law of The Republic of Indonesia Number 40 Year 2014 concerning Insurance

[8]. Fatwa Number 21/DSN-MUI/X/2001 regarding General Guidelines for Sharia Insurance

[9]. Wahbah Zuhaily, Al-Fiqh al-Islâmī wa Adilatuhu (Beirut: Dar al-Fikr, 1989) IV/ 291

[10]. Abdullâh Al-Imrânî, al- 'Uqûd al-Mâliyah al-Murakkabah: Dirâsat Fiqhiyah Ta'shiliyah wa Tathbîqiyah, (Riyadh: Esbelia, 2010) 43-44

[11]. Ibid. 46

[12]. Burhanuddin S., The Usage Rate of Multi Contractsn in Fatwa DSN-MUI, Journal Al-Ihkam, Volume 11, No. 1 Juni 2016, 209

[13]. Ibid.

[14]. Hasanuddin, The Concept and Standard of Hybrid Contracts in Fatwa DSN-MUI, Doctoral Dissertation, State Islamic Univerity Syarif Hidayatullah, Jakarta, 2008, 60

[15]. Ahmad Syarbâshî, Mu'jam al-Iqtishâdî al-Islâmî (Riyadh: Dar al-Jail, 1981) 254.

[16]. Ali al-Fayumi al-Maqry, Al-Misbâh al-Munîr (Beirut: Maktabah Lebanon, 1987) I/ 405

[17]. Wahbah Zuhailŷ, Ushûl al-Fiqh al-Islâmî (Beirut: Dar al-Fikr, 1406H) 1/208

[18]. Abdullâh Al-Imrânî, al- 'Uqûd al-Mâliyah al-Murakkabah, 180

[19]. Nazîh Hammâd, al- 'Uqûd al-Murakkabah fî al-Fiqh al-Islâmî, 11-12

[20]. Agustianto, Hybrid Contract dalam Keuangan Syariah. http://www.agustiantocentre.com/?p=68

[21]. Fatwa Number 21/DSN-MUI/X/2001 regarding General Guidelines for Sharia Insurance

[22]. Ibid.

[23]. Ibid

[24]. Fatwa Number 53/ DSN-MUI/III/ 2006 regarding Tabarru' Contract in Sharia Insurance

[25]. Fatwa Number 52/ DSN-MUI/III/ 2006 regarding Wakâlah bil 'Ujrah Contract in Shari'a Insurance and Reinsurance.

[26]. Fatwa Number 51/DSN-MUI/III/2006 regarding Mudharabah Musytarakah Contract in Sharia Insurance 